\title{
Changes in the composition of hind limb lymph after chemical injury
}

\author{
SUSAN BOYLES, G. P. LEWIS AND BARBARA WESTCOTT
}

CIBA Laboratories, Horsham, Sussex

\section{Summary}

1. Lymph was collected directly from the hind limbs of rabbits and cats anaesthetized with pentobarbitone.

2. Injury to the hind limb was caused by injection of one of two chemicals ; either dimethylsulphoxide (DMSO) which produced a mild injury, or croton oil which produced severe injury.

3. After subcutaneous injection $(6 \times 0.2 \mathrm{ml})$ into the right hind limb there was a good correlation between the changes in concentration of intracellular enzyme systems in the lymph draining the limb and the histological appearance of the injured tissue. DMSO caused an increase in cytoplasmic enzymes only, while after croton oil, which caused cell necrosis, there was an increase in the concentration of all intracellular enzymes examined.

4. There was an increased lymph flow accompanied by a fall in protein concentration after DMSO, while croton oil caused an increase in protein concentration and a variable effect on lymph flow.

\section{Introduction}

The present investigation is a continuation of earlier work on the changes which occur in lymph draining the hind limb after thermal injury in cats (Lewis, 1967), and in rabbits (Lewis, 1969). It was shown that the extent of cellular injury in the injured tissue could be determined by estimating the concentration in the lymph of different intracellular enzyme systems escaping from the damaged cells. The general conclusion was that a mild thermal injury was characterized by the appearance in the lymph of cytoplasmic enzymes, a more severe injury by increased mitochondrial enzymes as well, and the most severe injury, involving cell breakdown, resulted in an increase in the concentration of all intracellular constituents including lysosomal enzymes and potassium.

The purpose of the present investigation was to determine whether another type of tissue damage-chemical injury-could be assessed in the same way. Two noxious chemical substances were selected to produce different degrees of damage. Willoughby, Walters \& Spector (1966) investigated the reported anti-inflammatory effects of dimethylsulphoxide (DMSO) but found that instead of possessing antiinflammatory activity, DMSO produced an irritant action when injected into the skin of rats. This chemical was chosen for the present investigation to represent substances producing mild injury. Croton oil was used to produce a severe injury because its injection is known to lead to cell necrosis and it has been used effectively in the granuloma pouch technique by Robert \& Nezamis (1957). 
The morphological changes brought about by the two chemicals were also studied histologically in an attempt to correlate them with the biochemical events. A preliminary communication of this work was presented to the British Pharmacological Society (Boyles, Lewis \& Westcott, 1970).

\section{Methods}

The experiments were carried out on cats and rabbits anaesthetized with pentobarbitone sodium $40 \mathrm{mg} / \mathrm{kg}$. Hind limb lymph was collected from a cannula inserted in one of the femoral lymphatics and the limb was passively moved as described by Lewis \& Westcott (1968).

\section{Injury}

DMSO and croton oil were given by subcutaneous injection to the anaesthetized animal after a control sample of lymph had been collected from the same limb. Six injections each of $0.2 \mathrm{ml}$ were made at different sites in the leg.

\section{Biochemical estimations}

The following enzymes as well as protein and $\mathrm{K}^{+}$were estimated according to the methods described earlier; glutamic-oxalacetic transaminase (GOT), glutamic pyruvic transaminase (GPT), acid phosphatase and $\beta$-glucuronidase ; lactic dehydrogenase and cathepsin (Lewis, 1967, 1969).

\section{Histology}

Specimens of skin and muscle were taken from the injured limb and the uninjured contralateral limb after each experiment. The tissues were fixed in $10 \%$ buffered formalin for at least $24 \mathrm{~h}$. They were then dehydrated through increasing concentrations of alcohol from $70 \%$ to absolute, cleared in xylene and embedded in paraffin wax. Sections of $5 \mu \mathrm{m}$ thickness were cut and stained with Ehrlich's haematoxylin and eosin.

\section{Materials}

DMSO was obtained from Hopkin and Williams, and the croton oil was B.P.C. 1949.

\section{Results}

\section{Lymph flow, protein and $\mathrm{K}^{+}$concentration}

Thermal injury (Lewis, 1967, 1969) caused a marked increase in lymph flow accompanied by an increased protein concentration and with the more severe injuries an increased $\mathrm{K}^{+}$concentration as well. DMSO produced a similar increase in lymph flow but the protein concentration fell considerably. Figure 1 shows the result of a typical experiment in a cat; this inverse relationship was observed in both cats and rabbits. Croton oil produced a more variable result, sometimes causing an increase in flow and sometimes not. However, when there was an increase it was transient and usually accompanied by an increased protein concentration (Fig. 2). 


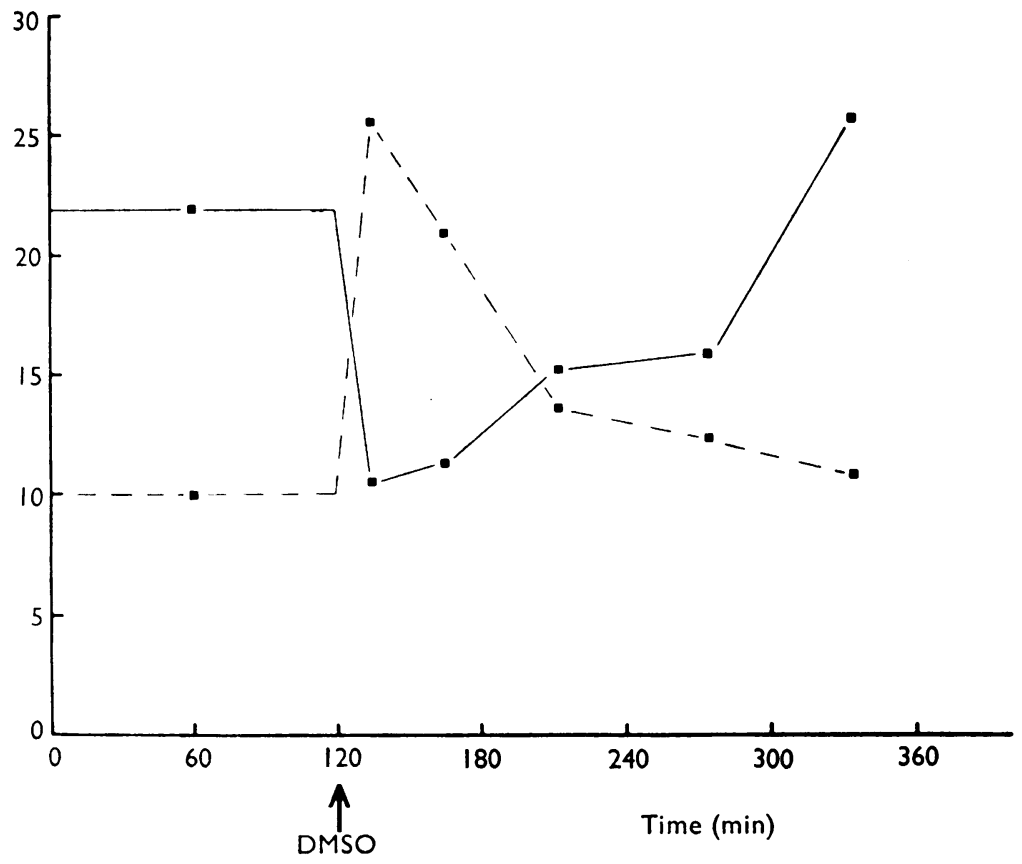

FIG. 1. Lymph flow $(\mu \mathrm{l} / \mathrm{min}, \square--\square)$ and protein concentration in the lymph $(\mathrm{mg} / \mathrm{ml}$, 10) from the hind limb of a cat anaesthetized with pentobarbitone. At the arrow $6 \times 0.2 \mathrm{ml}$ injections of DMSO were made subcutaneously.

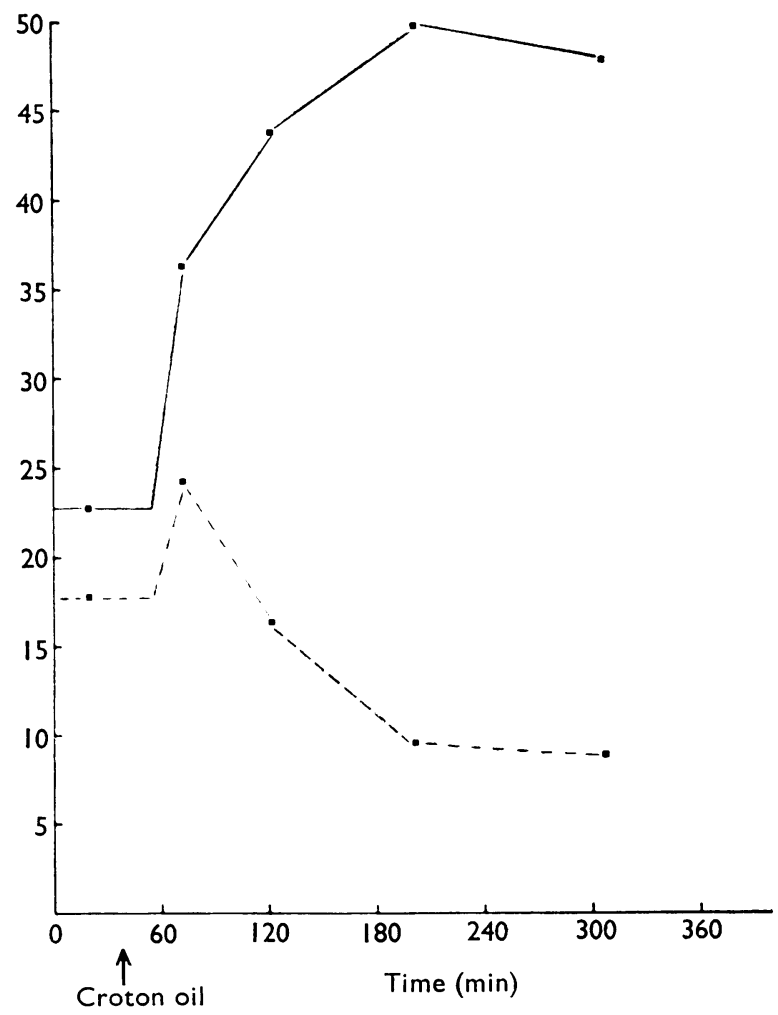

FIG. 2. Lymph flow $(\mu \mathrm{l} / \mathrm{min},-)^{--}$and protein concentration in the $1 \mathrm{ymph}(\mathrm{mg} / \mathrm{ml}$, fom the hind limb of a rabbit anaesthetized with pentobarbitone. At the arrow $6 \times 0.2 \mathrm{ml}$ injections of croton oil were made subcutaneously. 
Injection of DMSO did not result in an increase in the $\mathrm{K}^{+}$concentration in the lymph (Tables 1 and 2). After croton oil there was a significant increase in $\mathrm{K}^{+}$in both cats and rabbits (Tables 3 and 4).

\section{Changes in intracellular enzymes}

After administration of either chemical, there were changes in the concentration of some of the intracellular enzymes in the lymph. Injection of DMSO (Tables 1 and 2) caused a considerable increase in the concentration of the cytoplasmic enzymes LDH and GOT and a smaller increase in the concentration of the mitochondrial enzyme GPT. Figure 3 illustrates the result of a typical experiment in a cat and Fig. 4 that in a rabbit. In the experiments with DMSO the concentrations of lysosomal enzymes did not increase, but on the contrary, their concentrations decreased. This finding does not mean that the total amount of these enzymes leaving the leg was reduced for there was a concomitant increase in lymph flow. In the experiment of Fig. 3 in a cat, there was no increase in the concentration of mitochondrial enzyme GPT, whereas in the experiment of Fig. 4 in a rabbit, the concentration of this enzyme increased to nearly $400 \%$. A similar difference in the behaviour of GPT in cats and rabbits was also observed after mild thermal injury (Lewis, 1969).

Earlier, we had observed another species difference after mild thermal injury: the concentration of $\beta$-glucuronidase in the lymph increased in rabbits but not in cats. In the present experiments it was observed that the species difference was absent or at least present to a much smaller degree. As seen from the rabbit experiment of Fig. 4, there was only a small increase in $\beta$-glucuronidase after

TABLE 1. Enzyme levels in lymph and plasma of cats before and after subcutaneous injection of DMSO

\begin{tabular}{|c|c|c|c|c|c|c|c|}
\hline & & \multicolumn{3}{|c|}{ Lymph } & \multicolumn{3}{|c|}{ Plasma } \\
\hline & & Control & DMSO & $P$ value & Control & DMSO & $P$ value \\
\hline $\begin{array}{l}\text { LDH } \\
\text { GOT } \\
\text { GPT } \\
\text { Acid Phos. } \\
\beta \text {-Gluc. } \\
\text { Protein } \\
\text { Potassium }\end{array}$ & $\begin{array}{l}\text { mu./ml } \\
\mathrm{mu} . / \mathrm{ml} \\
\mathrm{mu} . / \mathrm{ml} \\
\mathrm{u} . / 100 \mathrm{ml} \\
\mathrm{u} . / 100 \mathrm{ml} \\
\mathrm{mg} / \mathrm{ml} \\
\text { mequiv./1. }\end{array}$ & $\begin{array}{c}232 \\
13.9 \\
11 \cdot 3 \\
8 \cdot 6 \\
947 \\
33 \cdot 0 \\
3 \cdot 5\end{array}$ & $\begin{array}{c}7,613 \\
116 \cdot 1 \\
22 \cdot 6 \\
3 \cdot 1 \\
906 \\
24 \cdot 8 \\
4 \cdot 4\end{array}$ & $\begin{array}{l}<0.001 \\
<0.001 \\
<0.02 \\
<0.01 * \\
\text { N.S. } \\
\text { N.S. } \\
\text { N.S. }\end{array}$ & $\begin{array}{c}156 \\
15.9 \\
13 \cdot 8 \\
2 \cdot 5 \\
711 \\
75 \cdot 4 \\
\cdot 3 \cdot 6\end{array}$ & $\begin{array}{c}257 \\
18 \\
23 \cdot 3 \\
1 \cdot 6 \\
1,167 \\
75 \cdot 6 \\
3 \cdot 6\end{array}$ & $\begin{array}{l}<0.02 \\
\text { N.S. } \\
\text { N.S. } \\
\text { N.S. } \\
\text { N.S. } \\
\text { N.S. } \\
\text { N.S. }\end{array}$ \\
\hline
\end{tabular}

* Indicates significant fall.

Each value is the mean of nine estimations from three animals. The enzymes were measured 4-5 $\mathrm{h}$ after injection. The $P$ values have been obtained using $t$ test for paired comparison. N.S. denotes that the mean difference was not significant.

TABLE 2. Enzyme levels in lymph and plasma of rabbits before and after subcutaneous injection of TABLE 2. Enzyme levels in lymph and plasma

\begin{tabular}{|c|c|c|c|c|c|c|c|}
\hline & & \multicolumn{3}{|c|}{ Lymph } & \multicolumn{3}{|c|}{ Plasma } \\
\hline & & Control & DMSO & $P$ value & Control & DMSO & $P$ value \\
\hline $\begin{array}{l}\text { LDH } \\
\text { GOT } \\
\text { GPT } \\
\text { Acid Phos. } \\
\beta \text {-Gluc. } \\
\text { Cathepsin } \\
\text { Protein } \\
\text { Potassium }\end{array}$ & $\begin{array}{l}\text { mu./ml } \\
\mathrm{mu} . / \mathrm{ml} \\
\mathrm{mu} . / \mathrm{ml} \\
\mathrm{u} . / 100 \mathrm{ml} \\
\mathrm{u.} / 100 \mathrm{ml} \\
\mathrm{u} . / \mathrm{ml} \\
\mathrm{mg} / \mathrm{ml} \\
\mathrm{mequiv} . / 1 .\end{array}$ & $\begin{array}{c}95 \\
6 \cdot 1 \\
11 \cdot 5 \\
5 \cdot 9 \\
310 \\
10 \cdot 2 \\
32 \\
3 \cdot 8\end{array}$ & $\begin{array}{c}6,485 \\
67 \\
24 \cdot 6 \\
2 \cdot 6 \\
408 \\
9 \cdot 2 \\
15 \cdot 5 \\
3 \cdot 9\end{array}$ & $\begin{array}{l}<0.001 \\
<0.001 \\
<0.01 \\
<0.02 * \\
\text { N.S. } \\
\text { N.S.S. } \\
<0.01 * \\
\text { N.S. }\end{array}$ & $\begin{array}{c}90 \\
12 \\
22 \cdot 1 \\
15 \cdot 5 \\
2,055 \\
14 \cdot 1 \\
63 \cdot 9 \\
4 \cdot 5\end{array}$ & $\begin{array}{c}54 \\
31 \cdot 1 \\
36 \cdot 2 \\
12 \cdot 5 \\
3,666 \\
14 \cdot 2 \\
67 \cdot 1 \\
4 \cdot 1\end{array}$ & $\begin{array}{l}\text { N.S. } \\
\text { N.S. } \\
<\text {.0.05 } \\
\text { N.S. } \\
\text { N.S. } \\
\text { N.S. } \\
\text { N.S. } \\
\text { N.S. }\end{array}$ \\
\hline
\end{tabular}

* Indicates significant fall.

Each value is the mean of nine estimations from three animals, The enzymes were measured $6 \mathrm{~h}$ after the injections. The $P$ values have been obtained using $t$ test for paired comparison. N.S. denotes that the mean difference was not significant. 


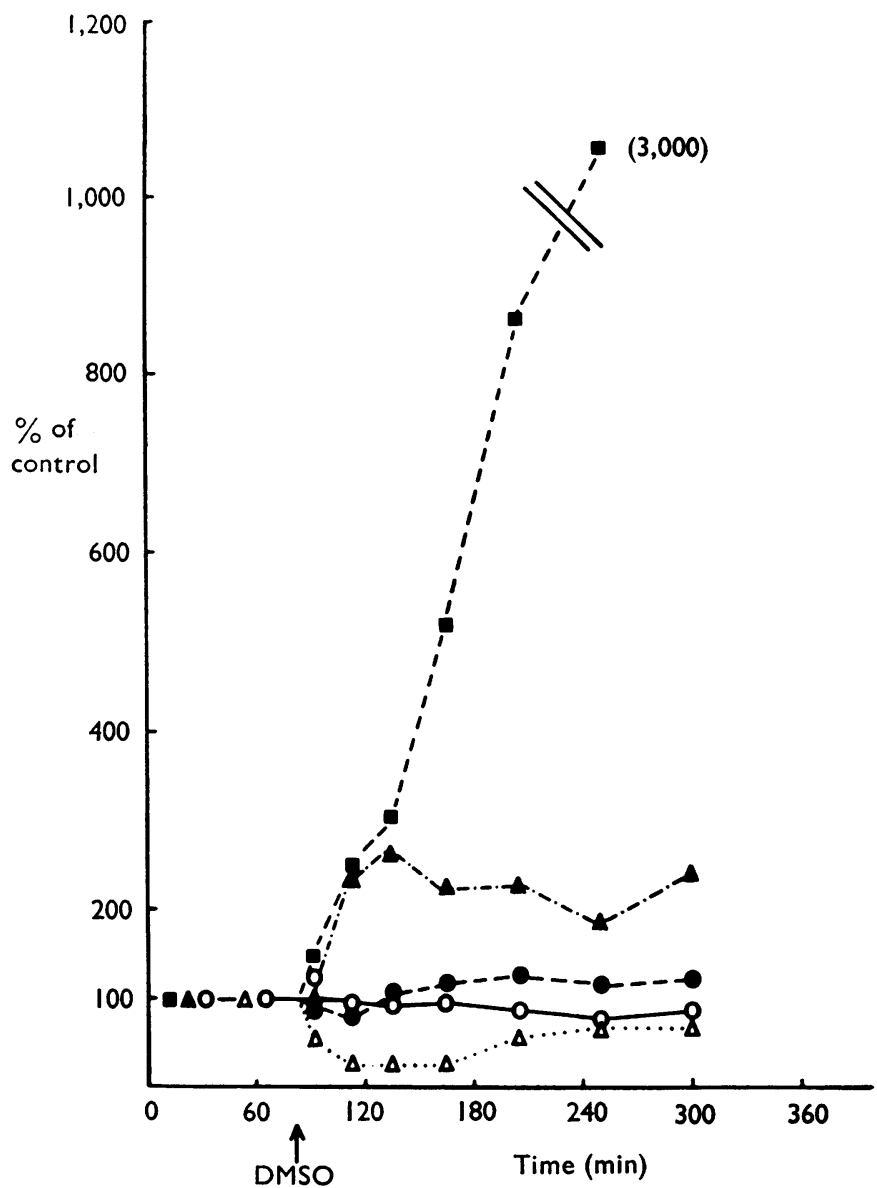

FIG. 3. Concentrations, expressed as \% of control, of LDH ( GPT $\left(\mathrm{C}_{---O)} ; \beta\right.$-glucuronidase $(\bigcirc-\bigcirc)$; and acid phosphatase $(\triangle \cdots \triangle \Delta)$ in the lymph collected from the hind limb of a cat anaesthetized with pentobarbitone, before and after subcutaneous injection of $6 \times 0.2 \mathrm{ml}$ DMSO.

DMSO and Table 2 shows that the mean value is not significantly increased after DMSO.

In both cats and rabbits there was an increase in the concentration of all enzymes in the lymph after injection of croton oil (Tables 3 and 4). The changes were more pronounced in the rabbit and one of these experiments is illustrated in Fig. 5.

In spite of the overall response being greater after croton oil, the increase in LDH activity was relatively less following injections of croton oil than after DMSO. This is shown by the lower probability values in the tables as well as from the experiment of Fig. 5. In the experiment illustrated in Fig. 6, however, in which croton oil was injected intramuscularly instead of subcutaneously, there was a greater increase in all enzymes and the most pronounced effect was with LDH. The strong effect on LDH activity following subcutaneous injection of DMSO might therefore reflect the ease with which DMSO diffuses into muscle.

With both DMSO and croton oil, the concentration of enzymes in the lymph started to increase soon after the injections and continued to increase for 4 to $6 \mathrm{~h}$, as long as the experiment was continued. 
Extent of injury produced by dilutions of croton oil

Since injection of undiluted croton oil produced a severe injury, it was of interest to discover whether dilutions of the chemical would produce a mild injury similar

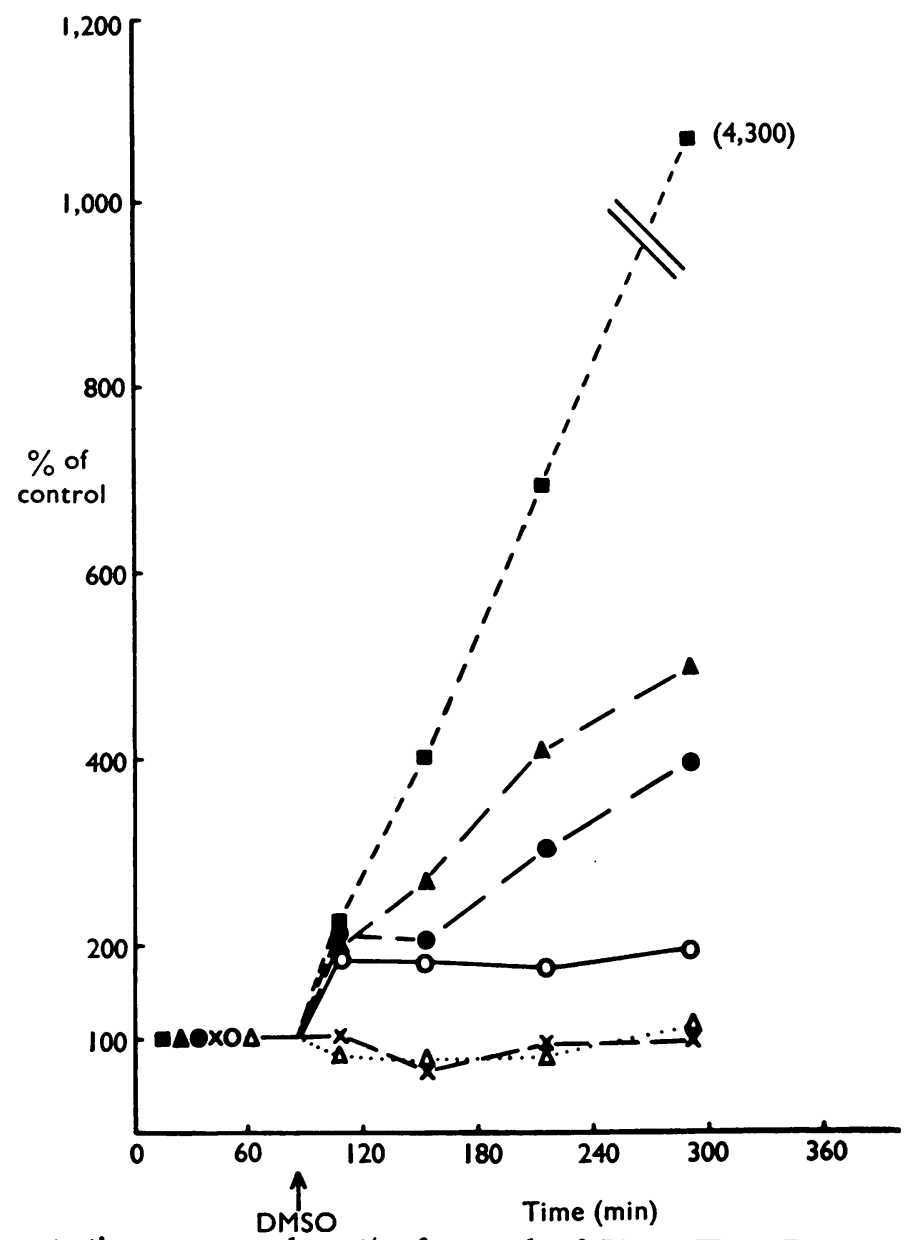

FIG. 4. Concentrations, expressed as \% of control, of LDH ( GPT $(-\cdots) ; \beta$-glucuronidase $(O-O)$; acid phosphatase $(\Delta \cdots, \Delta)$ and cathepsin $(X--x)$ in the lymph collected from the hind limb of a rabbit anaesthetized with pentobarbitone before and after subcutaneous injection of $6 \times 0.2 \mathrm{ml}$ DMSO.

TABLE 3. Enzyme levels in lymph and plasma of cats before and after subcutaneous injection of

\begin{tabular}{|c|c|c|c|c|c|c|c|}
\hline \multirow[b]{3}{*}{$\begin{array}{l}\text { LDH } \\
\text { GOT } \\
\text { GPT } \\
\beta \text {-Gluc. } \\
\text { Acid Phos. } \\
\text { Protein } \\
\text { Potassium }\end{array}$} & \multirow[b]{3}{*}{$\begin{array}{l}\mathrm{mu} . / \mathrm{ml} \\
\mathrm{mu} . / \mathrm{ml} \\
\mathrm{mu} . / \mathrm{ml} \\
\text { u./100 } \mathrm{ml} \\
\text { u. } / 100 \mathrm{ml} \\
\mathrm{mg} / \mathrm{ml} \\
\text { mequiv./1. }\end{array}$} & \multicolumn{3}{|c|}{ Lymph } & \multicolumn{3}{|c|}{ Plasma } \\
\hline & & Control & $\begin{array}{c}\text { Croton } \\
\text { oil }\end{array}$ & $P$ value & Control & $\underbrace{}_{\begin{array}{c}\text { Croton } \\
\text { oil }\end{array}}$ & $P$ value \\
\hline & & $\begin{array}{r}1,584 \\
57 \cdot 2 \\
15 \cdot 6 \\
1,663 \\
6 \cdot 3 \\
45 \cdot 6 \\
3 \cdot 0\end{array}$ & $\begin{array}{c}48,677 \\
175 \\
43 \cdot 4 \\
8,492 \\
10 \cdot 7 \\
54 \cdot 3 \\
5 \cdot 1\end{array}$ & $\begin{array}{l}<0.05 \\
<0.001 \\
<0.05 \\
<0.001 \\
\text { N.S. } \\
\text { N.S. } \\
<0.001\end{array}$ & $\begin{array}{r}1,429 \\
45 \cdot 1 \\
14 \cdot 6 \\
1,481 \\
2 \cdot 3 \\
66 \cdot 1 \\
3 \cdot 7\end{array}$ & $\begin{array}{r}2,413 \\
15 \cdot 8 \\
12 \cdot 8 \\
1,795 \\
0 \cdot 8 \\
84 \cdot 0 \\
3 \cdot 9\end{array}$ & $\begin{array}{l}\text { N.S. } \\
\text { N.S. } \\
\text { N.S. } \\
\text { N.S. } \\
\text { <.0.01* } \\
\text { N.S. } \\
\text { N.S. }\end{array}$ \\
\hline
\end{tabular}

* Indicates significant fall.

Each value is the mean of nine estimations from three animals. The enzymes were measured $5-6.5 \mathrm{~h}$ after the injections. The $P$ values have been obtained using $t$ test for paired comparison. N.S. denotes that the mean difference was not significant. 


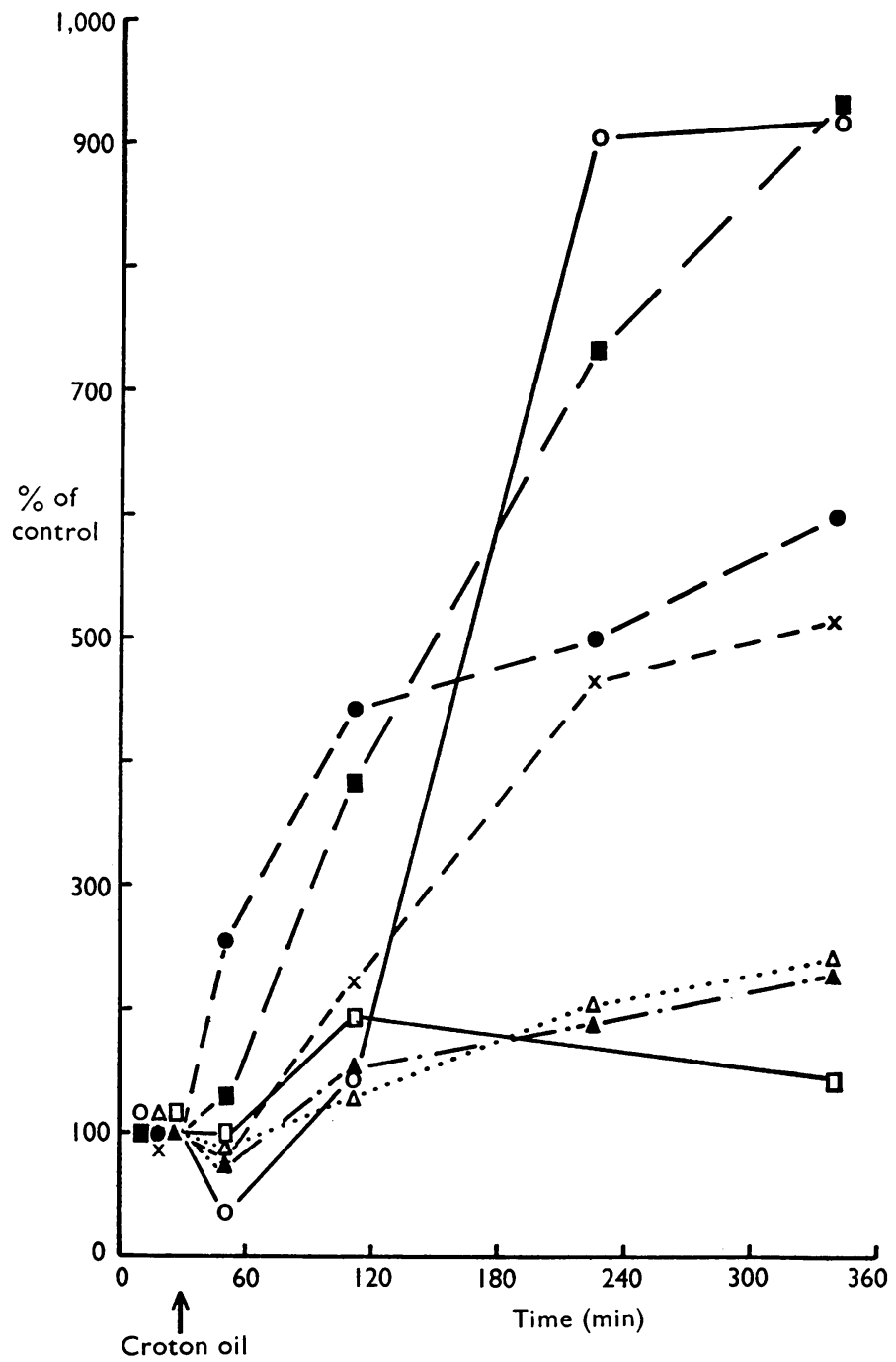

FIG. 5. Concentrations, expressed as \% of control, of LDH ( GPT $(0-\cdots) ; \beta$-glucuronidase $(\bigcirc-\bigcirc) ;$ acid phosphatase $(\triangle \cdots \cdot \triangle) ;$ cathepsin $\left(X-X^{-}\right)$and $\mathrm{K}+(\square-\square)$ in the lymph collected from the hind limb of a rabbit anaesthetized with pentobarbitone before and after subcutaneous injection of $6 \times 0 \cdot 2 \mathrm{ml}$ croton oil.

TABLE 4. Enzyme levels in lymph and plasma of rabbits before and after subcutaneous injection of croton oil

Lymph

\begin{tabular}{|c|c|c|c|c|c|c|c|}
\hline & & & & & \multirow{2}{*}{\multicolumn{3}{|c|}{ Croton }} \\
\hline & & \multicolumn{3}{|c|}{ Croton } & & & \\
\hline & & Control & oil & $P$ value & Control & oil & $P$ value \\
\hline LDH & mu. $/ \mathrm{ml}$ & 213 & 6,800 & $<0.01$ & $86 \cdot 5$ & $58 \cdot 75$ & N.S. \\
\hline GOT & $\mathrm{mu} . / \mathrm{ml}$ & $21 \cdot 4$ & $83 \cdot 7$ & $<0.05$ & $13 \cdot 5$ & $27 \cdot 3$ & $<0.01$ \\
\hline GPT & mu./ml & $4 \cdot 6$ & $21 \cdot 1$ & $<0.01$ & $17 \cdot 5$ & $19 \cdot 6$ & N.S. \\
\hline Acid Phos. & u. $/ 100 \mathrm{ml}$ & $4 \cdot 7$ & $16 \cdot 5$ & $<0.01$ & $16 \cdot 3$ & $20 \cdot 1$ & N.S. \\
\hline$\beta$-Gluc. & u. $/ 100 \mathrm{ml}$ & 296 & 4,219 & $<0.001$ & 2,138 & 5,773 & $<0.002$ \\
\hline Cathepsin & $\mathrm{u} . / \mathrm{ml}$ & 10 & $76 \cdot 1$ & $<0.05$ & $18 \cdot 4$ & $17 \cdot 0$ & N.S. \\
\hline Protein & $\mathrm{mg} / \mathrm{ml}$ & $30 \cdot 6$ & $35 \cdot 4$ & N.S. & $61 \cdot 7$ & $74 \cdot 3$ & N.S. \\
\hline Potassium & mequiv./1. & $3 \cdot 5$ & $5 \cdot 2$ & $<0.002$ & $4 \cdot 03$ & $3 \cdot 9$ & N.S. \\
\hline
\end{tabular}

Each value is the mean of nine estimations from three animals. The enzymes were measured $4-5 \mathrm{~h}$ after the injections. The $P$ values have been obtained using $t$ test for paired comparison. N.S. denotes that the mean difference was not significant. 
to that produced by DMSO. In Fig. 7 are plotted the concentrations of several enzymes in the lymph draining the hind limb into which croton oil, $1 \%, 10 \%, 30 \%$, $50 \%, 75 \%$ diluted in corn oil had been injected. It is clear that only the $75 \%$ dilution caused a significant increase in the lymph of any of the enzyme concentrations so that the effect was more characteristic of an all-or-none response than a dose response relationship. It can be seen from Fig. 7 that all the enzymes, irrespective of their intracellular localization, behaved similarly after injections of the different dilutions of croton oil. These changes were not similar to those after injection of DMSO.

\section{Histological changes}

Specimens of skin and muscle were taken after each experiment from the treated limb and the contralateral untreated hind limb and examined by light microscopy.

After injection of DMSO no cellular changes could be observed in the cells of skin or the muscle of the treated or contralateral limb. Occasionally there were signs of vasodilatation in the treated limb, but even this effect was not pronounced.

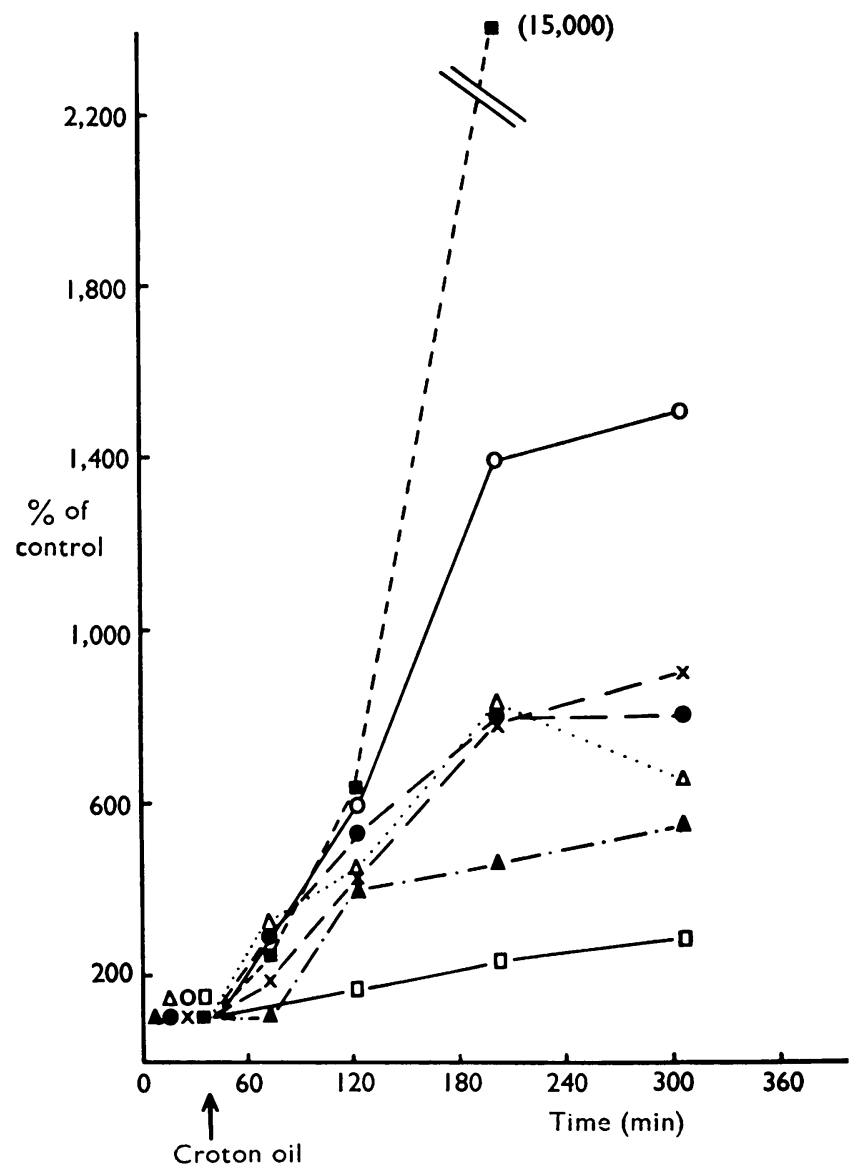

FIG. 6. Concentrations, expressed as \% of control, of LDH ( $\left.-{ }_{--}\right)$; GOT $\left(\Delta_{-} \cdot-\cdot-\Delta\right)$; GPT $(0-\cdots) ; \beta$-glucuronidase $(\bigcirc-O)$; acid phosphatase $(\triangle \cdots \cdots \triangle)$; cathepsin $(X \ldots .-X)$ and $K+(\square-\square)$ in the lymph collected from the hind limb of a rabbit anaesthetized with pentobarbitone before and after intramuscular injection of $6 \times 0.2 \mathrm{ml}$ croton oil. 
In contrast there were several signs of tissue damage in limbs which had been treated with croton oil. There was a pronounced vasodilatation in the skin and muscle and most blood vessels contained leucocytes. In many instances polymorphonuclear leucocytes had migrated into the extravascular space. In addition, there were three histological changes in the muscle. Firstly, the bundles of fibres were separated from each other, probably as a result of oedema. Secondly, many of the bundles had in cross section become rounded or globular in appearance. Finally, in some areas there was the appearance of vacuolization with a breakdown of the fibres inside the sarcolemma.

\section{Discussion}

The general conclusion from this investigation is that as with thermal injury the degree of cellular injury produced by injection of noxious chemicals can be assessed by studying the changes in the concentrations of intracellular enzyme systems in the lymph draining the injured area. DMSO produced a mild injury as judged by the macroscopic and microscopic appearance of the injected limb and caused the increase in the lymph of only cytoplasmic enzymes LDH and GOT and a small increase in mitochondrial enzyme GPT. The effect was similar to that produced by a mild thermal injury, for example a surface scald at $60^{\circ} \mathrm{C}$ for $1 \mathrm{~min}$. Croton oil, on the other hand, caused a more severe injury producing histological changes resembling those after a severe thermal injury, for example a surface scald at $80^{\circ} \mathrm{C}$ for 15-20 s or freezing the limb. The concentration in the lymph not only of cytoplasmic enzymes but also of mitochondrial enzymes and lysosomal enzymes

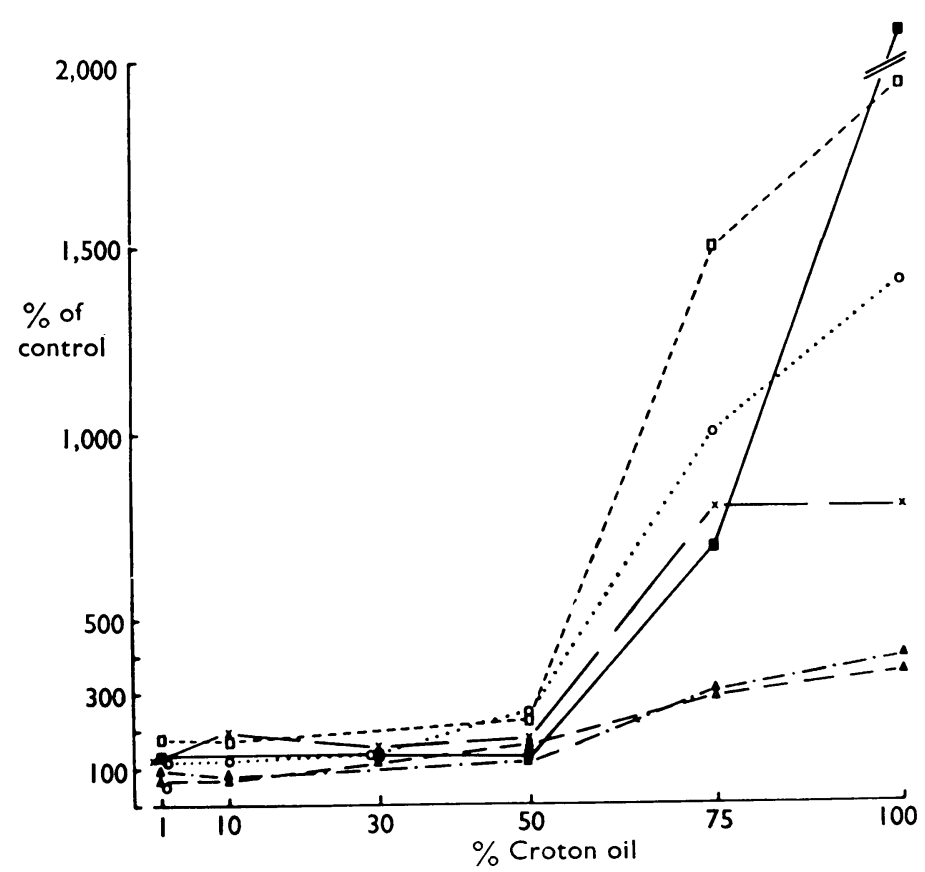

FIG. 7. Concentrations, expressed as \% of control, of LDH ( $\square$ - CPK ( $\square---\square)$; GOT $(\Delta-\cdots-\Delta) ; \beta$-glucuronidase $(\bigcirc \cdots \cdots \bigcirc)$; acid phosphatase $(\triangle--\triangle)$ and cathepsin $(X-\ldots-X)$ in the lymph collected from the hind limbs of rabbits anaesthetized with pentobarbitone, 4-6 $\mathrm{h}$ after subcutaneous $6 \times 0.2 \mathrm{ml}$ injections of croton oil, undiluted or diluted to a final concentration of $1,10,30,50$ or $75 \%$ in corn oil. 
increased, and this is consistent with the extensive cell necrosis observed histologically.

These findings do not support the view that lysosomal enzymes initiate the tissue reaction to all kinds of injury since after chemical injury in the present experiments, as with thermal injury, lysosomal enzymes do not enter the extracellular space preferentially but only together with the other intracellular enzyme systems as a result of cell breakdown. The present experiments do not, however, assess any activation of lysosomal enzymes which might occur inside the cell.

When croton oil was diluted with the innocuous vehicle corn oil only $75 \%$ croton oil produced injury, higher dilutions producing no significant effect. It was found that, although the increase in the concentrations of enzymes in the lymph was less with $75 \%$ croton oil than after the undiluted substance, there was nevertheless an increase in all the enzymes, cytoplasmic, mitochondrial and lysosomal. This finding indicated that the injury involved complete breakdown of cells, although less than the number involved following injection of undiluted croton oil. Thus it must be concluded that even croton oil diluted to $75 \%$ causes a strong cellular injury. This is in contrast to the mild chemical injury brought about by DMSO since in those experiments the cells were not broken down and only cytoplasmic enzymes and low concentrations of mitochondrial enzymes appeared in the lymph.

Willoughby, Walters \& Spector (1966), using the technique of injecting colloidal carbon, found that the most prominent change after DMSO occurred in the capillaries and not the venules which are regarded as the site of protein exudation after injury. They observed that immediately after intrapleural DMSO the transudate contained a low concentration of protein whereas $2 \mathrm{~h}$ after injection, the protein concentration increased. They suggest an early loss of fluid from the micro-vessels with little alteration of vascular permeability to protein followed by a loss of protein-rich fluid from the venules after $2 \mathrm{~h}$. The present results generally agree with their findings since the protein concentration of the lymph decreased considerably immediately after injection of DMSO and the lymph flow increased. After $2 \mathrm{~h}$ the protein concentration increased although it did not usually reach a concentration much above the normal level. On the other hand, croton oil presumably damages the venules and usually produces an exudate of high protein concentration.

An alternative explanation is that the fluid which goes to increase lymph flow after injection of DMSO does not originate in the blood but in the injured cells of the limb. The concentration of the lysosomal enzyme acid phosphatase was also reduced in the lymph after injection of DMSO. This was probably also the result of dilution, although it is difficult to understand why all the lysosomal enzymes were not diluted in the same way.

The pronounced increase of lymph flow which occurred after DMSO in spite of decreased protein concentration gives support to the view that lymph flow is not primarily controlled by the protein concentration of the interstitial fluid. It might be that after injury, some cell constituents enter the interstitial space and increase the osmotic pressure sufficiently to draw the extra water from the cells or from the blood vessels.

\section{REFERENCES}

Boyles, Susan, Lewis, G. P. \& Westcott, Barbara (1970). Intracellular enzymes in local lymph after chemical injury. Br. J. Pharmac., 38, $441 P$. 
LEWIs, G. P. (1967). Intracellular enzymes in local lymph as a measure of cellular injury. J. Physiol., Lond., 191, 591-607.

LEwIS, G. P. (1969). Changes in the composition of rabbit hind limb lymph after thermal injury. J. Physiol., Lond., 205, 619-634.

LEWIS, G. P. \& WESTCOTT, B. (1968). Intracellular enzymes in rabbit hind-limb lymph after injury. J. Physiol., Lond., 195, 12-13P.

Robert, A., \& NeZAMIS, J. E. (1957). The granuloma pouch as a routine assay for antiphlogistic compounds. Acta Endocr., 25, 105-112.

WilloughBY, D., Walters, M. \& SPECTOR, W. (1966). An analysis of the irritant action of dimethylsulphoxide. J. Path. Bact., 91, 195-205.

(Received April 22, 1970) 